\title{
Effectiveness of early therapeutic intervention in phases one and two after COVID-19 infection: systematic review
}

\author{
Laura Faustino Gonçalves ${ }^{1} \odot$, Guilherme de Souza Cipriano ${ }^{\circledR}$,

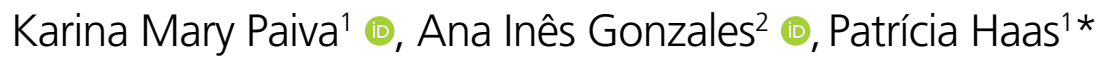

\begin{abstract}
SUMMARY
OBJECTIVES: Although research in relation to new vaccines for the coronavirus, SARS-CoV-2 (COVID-19), is ongoing, it has been reported that medical teams are also considering the use of antiviral drugs in patients in order to verify their effectiveness when infection signs and symptoms present, mainly in stages one and two of the disease.

METHODS: For the selection of studies, the combination based on the Medical Subject Heading Terms (MeSH) was used, and the databases Medline (Pubmed), LILACS, SciELO, SCOPUS, Web of Science, and BIREME were searched. The search period for articles consisted of manuscripts published between January 2010 and July 2020 without language and localization restrictions.

RESULTS: Initially, 20 articles were selected and then reduced to 19 after exclusion based on repetititve articles. Titles and abstracts were analyzed, and 14 articles were excluded because they did not meet the inclusion criteria and did not answer the guiding question. Studies show that patients receiving certain medications in the initial stages (one and two) indicate a reversal of complications during hospitalization or often do not require hospitalization in addition to being discharged in a shorter period of time.

CONCLUSION: Studies have reported that effective drugs for treating COVID-19 exist. In addition, this study emphasizes the importance of performing therapeutic interventions in the initial stages of infection aimed at reversing the disease and minimizing public health costs. KEYWORDS: Coronavirus Infection. Therapy. Drug therapy. Systematic review.
\end{abstract}

\section{INTRODUCTION}

The new coronavirus, SARS-CoV-2 (COVID-19) was initially identified in December 2019 in Wuhan, China. The epidemic's epicenter quickly moved to the European continent and, in March 2020, it was classified as a pandemic by the World Health Organization (WHO), making it a worldwide public health concern ${ }^{1,2}$. The disease has reached more than 12,102,328 million cases and 551,046 thousand deaths worldwide, in addition to more than 5 million confirmed cases worldwide ${ }^{3}$.
Disease symptoms usually begin with fever associated with dry cough and fatigue and, after a week, can cause breathing difficulties with many patients needing hospitalization and hospital treatment due to the evolution of the disease. The time from the onset of symptoms to the need for a patient to be taken to the intensive care unit (ICU) occurs on an average of 10 days after infection ${ }^{4}$. So far, the treatment of individuals infected with COVID-19 with moderate/severe symptoms that give an indication of hospitalization consists of offering respiratory support, in addition to other measures, until the immune

\footnotetext{
'Universidade Federal de Santa Catarina, Faculdade de Fonoaudiologia - Florianópolis (SC), Brazil.

Universidade do Estado de Santa Catarina, Centro de Ciências da Saúde e do Esporte - Florianópolis (SC), Brazil.

*Corresponding author: patrícia.haas@ufsc.br

Conflicts of interest: the authors declare there are no conflicts of interest. Funding: none.

Received on September 20, 2020. Accepted on December 10, 2020.
} 
system is able to fight the virus ${ }^{4}$ COVID-19 can be divided into three phases with different manifestations, treatment, and prognosis. The antirheumatic drug with antiviral and antibiotic activities seems to be capable of playing an important role in the treatment of COVID-19 to avoid complications that require invasive ventilation ${ }^{5}$.

COVID-19 can be differentiated in three progressive stages $^{6-8}$. The first phase is a viral phase normally characterized by fever, fatigue, dry cough, anosmia, altered taste, nasal congestion, and diarrhea ${ }^{7}$. The second phase is a pulmonary phase characterized by dyspnea and hypoxia. The third phase is characterized by respiratory distress that can develop into a clinical manifestation of vasculitis with embolism, septic shock, and metabolic acidosis? ${ }^{9}$. These symptoms correspond to those reported by the patients and the health team but are not exclusive of other observations of symptoms.

Although much research has been done in relation to new vaccines, it is reported that medical teams are also trying to reconcile the use of antiviral drugs in order to verify their effectiveness in the presence of infective disease symptoms and to adapt to their local conditions and populations, seeking to avoid the collapse of hospitals in both the public and private healthcare sectors ${ }^{4}$. In this sense, the main and guiding objective of the present research was to verify the scientific evidence on the therapeutic intervention in phases one and two after infection by COVID-19 in order to answer the research question: How effective are the intervention phases one and two after COVID-19 infection?

\section{METHODS}

\section{Protocol and registration}

The systematic review was conducted according to the recommendations of the Preferred Reporting Items for Systematic Reviews and Meta-Analyzes (PRISMA) ${ }^{10}$. Searches for scientific articles were conducted by two independent researchers using the electronic databases MEDLINE (PubMed) (https://www. ncbi.nlm.nih.gov/pubmed/), LILACS (http://lilacs.bvsalud. org/), SciELO (http://www.scielo.br/), BIREME (https://bvsalud.org/), SCOPUS, and WEB OF SCIENCE from January 2010 to July 2020. The research was structured and organized in the PICOS format, which represents an acronym for target population, intervention, comparison, outcomes, and study (Table 1).

\section{Research strategy}

The descriptors were selected from the Health Sciences Descriptors (DeCS) and Medical Subject Heading Terms
$(\mathrm{MeSH})$ dictionaries, given their wide use by the scientific community for indexing articles in the PubMed database. The following keywords and Boolean operators were proposed for the searches: ([coronavirus] and [covid-19] and [phases] and [treatment] and [disease progression]). The articles were identified through electronic search and then organized and reviewed independently for duplication by the two authors. Subsequently, the titles of the articles were also analyzed independently. Articles that did not fulfill any inclusion criteria were excluded. In the sequence, the abstracts of the articles selected in the second step were examined. Articles that did not contain characteristics of the question to be answered were excluded at this stage.

\section{Eligibility criteria}

The designs of epidemiological studies with possibilities for admission to this research were descriptive, cross-sectional, cohort, and case study. Publications were included without language and localization restrictions. The article search period ranged from January 2010 to July 2020. Studies published in the form of letters to the editor, guidelines, literature and systematic reviews, meta-analyses, and abstracts were excluded. Table 2 represents the inclusion and exclusion criteria used in this research.

\section{Risk of bias}

The quality of the methods used in the included studies was independently assessed by the reviewers according to the PRISMA recommendation ${ }^{10}$. The assessment prioritized clear description of the information. At this point, the review was carried out blindly, masking the names of the authors and magazines, and avoiding any potential bias and conflict of interests.

\section{Exclusion criteria}

Studies published in the form of letters to the editor, guidelines, literature, narrative, and systematic reviews, meta-analyses

Table 1. Description of the pico components.

\begin{tabular}{l|c}
\hline Acronym & Definition \\
\hline P & Patients \\
\hline I & COVID-19 \\
\hline C & Therapy \\
\hline O & Intervention \\
\hline S & $\begin{array}{c}\text { Descriptive study } \\
\text { Cross-sectional study } \\
\text { Observational study }\end{array}$ \\
\hline
\end{tabular}

Source: developed by the authors. 
Table 2. Summary of the inclusion and exclusion criteria.

\begin{tabular}{l|c}
\hline Inclusion criteria & Case reports \\
Design & $\begin{array}{c}\text { Case-control studies } \\
\text { Controlled clinical trials } \\
\text { Cohort studies } \\
\text { Screening studies } \\
\text { Observational studies }\end{array}$ \\
\hline Localization & No restriction \\
\hline Language & No restriction \\
\hline Exclusion criteria & Letters to the editor \\
Guidelines \\
Design
\end{tabular}

Source: developed by the authors.

and abstracts were excluded. Studies with unclear descriptions, or unavailable in their entirety were also excluded (Table 2).

\section{DATA ANALYSIS}

The extraction of data for the eligibility process of the studies was performed using a specific form for systematic review prepared by two researchers in Excel $^{\circledR}$, in which the extracted data were initially added by one of the researchers and then checked by the other. They were initially selected according to the title, after which abstracts were then analyzed and only those that were potentially eligible were selected. Based on their abstracts, articles were selected for full reading and those that met all predetermined criteria were included. In case of disagreement between evaluators, a third evaluator made the decision on the eligibility of the study in question.

\section{Selection of studies}

Initially, the eligibility reviewers were trained to perform the systematic review by other reviewers. After calibration and clarification of doubts, the titles and abstracts were independently examined by the two eligibility reviewers. Those who presented a title within the scope but with an unavailable abstract were also obtained and analyzed in full. Subsequently, the eligible studies were obtained in full text and evaluated. In specific cases, when the study with potential for eligibility presented incomplete data, the authors could be contacted by e-mail for further information; however, this communication was not necessary for any of the articles. In case of disagreement between the reviewers, a third party was involved for the final decision.

\section{Data collection}

After screening, the texts of the selected articles were reviewed and extracted in a standardized manner by two authors under supervision by identifying the year of publication, place of research, language of publication, type of study, sample, method, results, and conclusion of the study.

\section{Clinical outcome}

The clinical result of interest consisted of verifying the scientific evidence about the therapeutic intervention in phases one and two after infection of COVID-19. Those who did not use this approach were not used for the literature review sample.

\section{RESULTS}

Initially, 20 articles were selected and then reduced to 19 after exclusion by repetition. Titles and abstracts were analyzed and 14 papers were excluded for not meeting the inclusion criteria that characterized the guiding question, so 4 articles were admitted for the final analysis ${ }^{1-14}$. The studies selected for the research were of the randomized controlled, multicenter, and descriptive type, as they answered the guiding question and were eligible according to the PRISMA ${ }^{10}$ criteria used for the development of this research (Figure 1).

From the chosen descriptors, the databases of the scientific bases were consulted and the results available in Table 3 were obtained.

Regarding the description of the results of the articles eligible in this study, the information is verified in detail in Table 4. The information of the study samples, selected intervention protocols, associated comorbidities, therapeutic management, symptoms present at the beginning of treatment, medication use, recovery time, and age of individuals are highlighted in this table.

As for the sample of studies included in this research, the number of studies corresponded to $\mathrm{n}=1,010$ individuals. The individuals undergoing antiviral therapy using remdesivir were 41, oseltamivir 599, and individuals with no therapy formed the rest of the patient sample. In the study by Wang et al. ${ }^{13}$, the authors aimed to evaluate the efficacy and safety of using the drug remdesivir in adults who had COVID-19 symptoms for 12 days or less. Patients received intravenous remdesivir (200 mg on day 1 followed by $100 \mathrm{mg}$ on days 2 


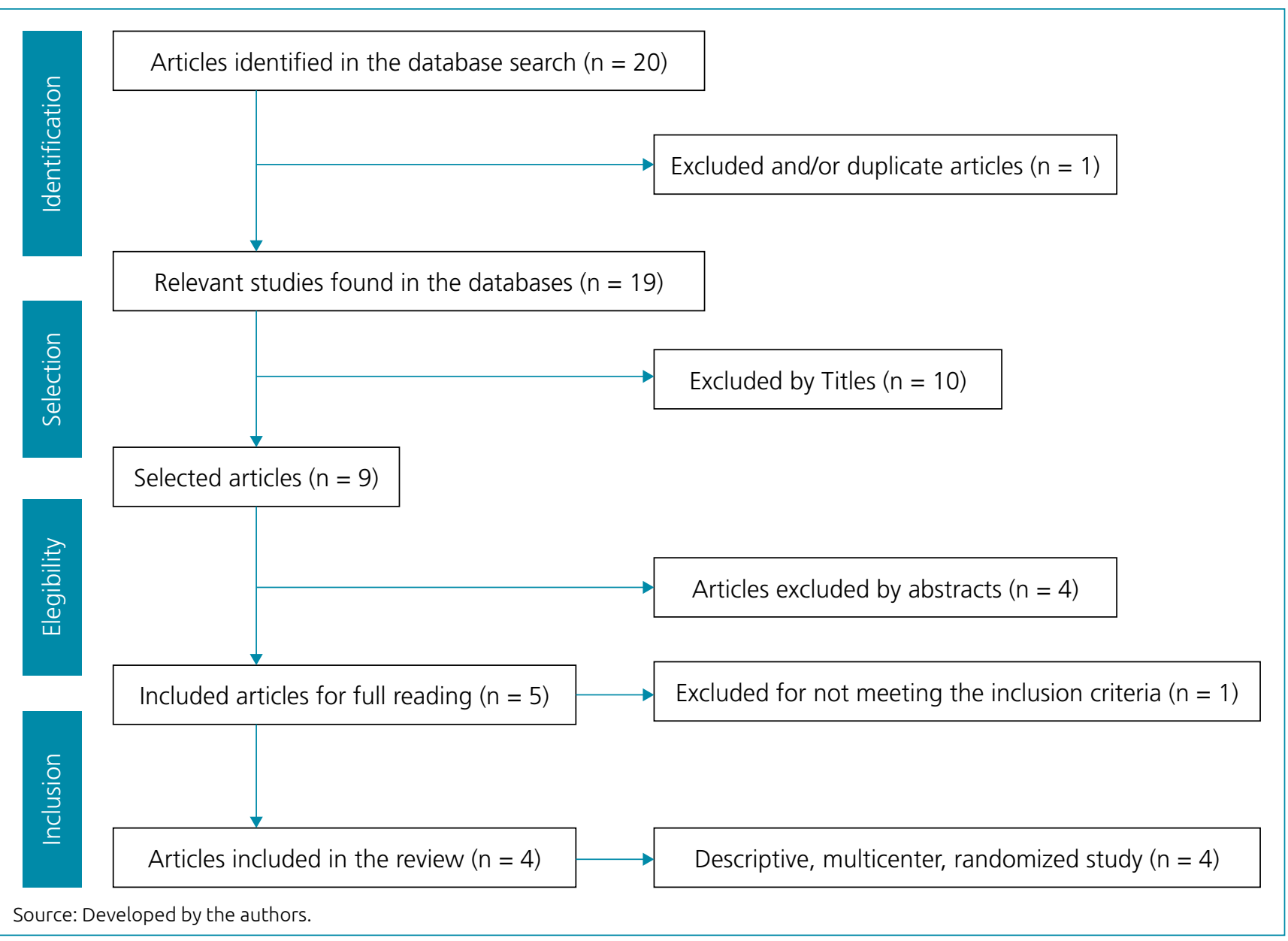

Figure 1. Flowchart of the search process.

Table 3. Classification of references obtained from the PubMed, SciELO, LILACS, Web of Science, and Scopus databases.

\begin{tabular}{|c|c|c|c|c|c|}
\hline Keywords & $\begin{array}{l}\text { Number } \\
\text { of articles }\end{array}$ & $\begin{array}{l}\text { References } \\
\text { excluded }\end{array}$ & Reason & Selected & Database \\
\hline $\begin{array}{l}\text { (coronavirus) and (covid-19) and (phases) and } \\
\text { (treatment) and (disease progression) }\end{array}$ & 0 & 0 & 0 & - & SCIELO \\
\hline $\begin{array}{l}\text { (coronavirus) and (covid-19) and (phases) and } \\
\text { (treatment) and (disease progression) }\end{array}$ & 0 & 0 & 0 & - & LILACS \\
\hline $\begin{array}{l}\text { (coronavirus) and (covid-19) and (phases) and } \\
\text { (treatment) and (disease progression) }\end{array}$ & 12 & 10 & $\begin{array}{l}\text { Excluded by title } \\
\text { (9), addressing } \\
\text { another topic (1); }\end{array}$ & 2 & BIREME \\
\hline $\begin{array}{l}\text { (coronavirus) and (covid-19) and (phases) and } \\
\text { (treatment) and (disease progression) }\end{array}$ & 0 & 0 & 0 & - & Scopus \\
\hline $\begin{array}{l}\text { (coronavirus) and (covid-19) and (phases) and } \\
\text { (treatment) and (disease progression) }\end{array}$ & 0 & 0 & 0 & - & $\begin{array}{l}\text { Web of } \\
\text { Science }\end{array}$ \\
\hline $\begin{array}{l}\text { (coronavirus) and (covid-19) and (phases) and } \\
\text { (treatment) and (disease progression) }\end{array}$ & 8 & 6 & $\begin{array}{l}\text { Duplicates (1); } \\
\text { Excluded by } \\
\text { title (5) }\end{array}$ & 2 & PubMed \\
\hline Total & 20 & 16 & & 4 & $\begin{array}{l}\text { BIREME } \\
\text { PubMed }\end{array}$ \\
\hline
\end{tabular}

Source: Developed by the authors. 
Table 4. Summary of the included articles.

\begin{tabular}{|c|c|c|c|c|c|}
\hline $\begin{array}{l}\text { Author/ } \\
\text { Year }\end{array}$ & $\begin{array}{l}\text { Objective of } \\
\text { the Study }\end{array}$ & $\begin{array}{l}\text { Study } \\
\text { Design } \\
\text { Sample }\end{array}$ & $\begin{array}{l}\text { Description/ } \\
\text { Intervention } \\
\text { Protocol }\end{array}$ & $\begin{array}{c}\text { Results/ } \\
\text { Outcomes }\end{array}$ & Conclusion \\
\hline $\begin{array}{l}\text { Beigel } \\
\text { et al. }{ }^{11}, \\
2020\end{array}$ & $\begin{array}{l}\text { To evaluate } \\
\text { the clinical } \\
\text { effectiveness } \\
\text { and safety } \\
\text { of using } \\
\text { remdesivir in } \\
\text { adults } \\
\text { hospitalized } \\
\text { with COVID-19 }\end{array}$ & $\begin{array}{c}\text { RCT } \\
\text { Multicenter }\end{array}$ & $\begin{array}{l}\text { The individuals in } \\
\text { the study sample } \\
\text { came from different } \\
\text { countries and were } \\
\text { hospitalized with or } \\
\text { without supplemental } \\
\mathrm{O}_{2} \text {, non-invasive MV, } \\
\text { and invasive MV. } \\
\text { TG: } \mathrm{n}=538 \\
\text { Intravenous } \\
\text { remdesivir: } 200 \text { mg } \\
\text { on day } 1 \text { and } 100 \mathrm{mg} \\
\text { from day } 2 \text { to day } \\
\text { 10, or until hospital } \\
\text { discharge. } \\
\text { PG: } \mathrm{n}=521 \\
\text { Received a placebo } \\
\text { infusion on the same } \\
\text { days as the treatment } \\
\text { group. }\end{array}$ & 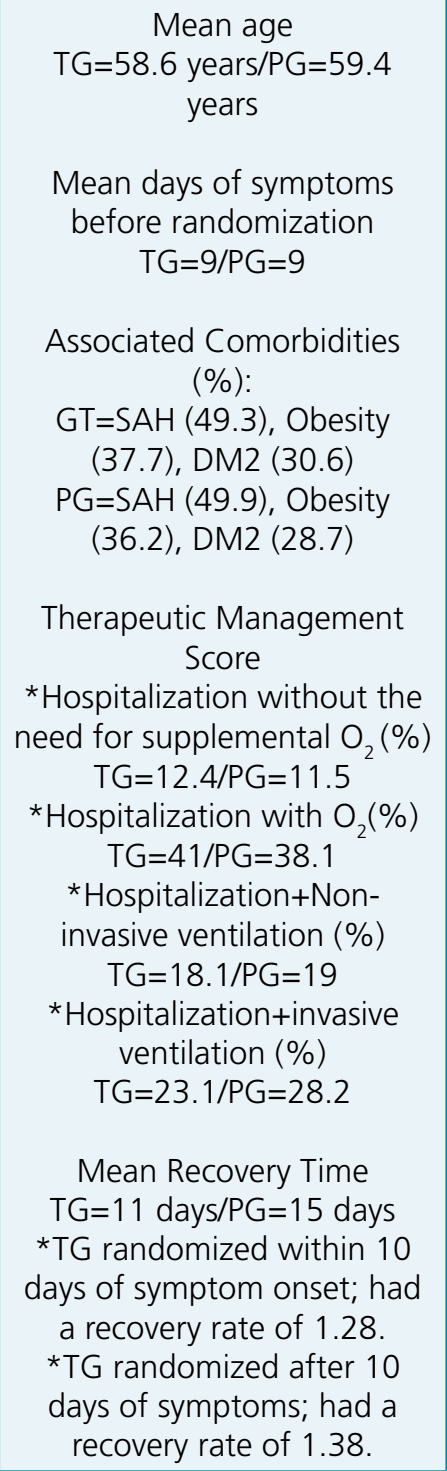 & $\begin{array}{l}\text { Using remdesivir for } \\
10 \text { days in the TG } \\
\text { had better results } \\
\text { than the placebo } \\
\text { when treating } \\
\text { hospitalized } \\
\text { patients with } \\
\text { COVID-19. } \\
\text { The results were } \\
\text { better in the TG } \\
\text { patients who were } \\
\text { given remdesivir } \\
\text { while receiving } \\
\text { supplemental } \mathrm{O}_{2} \text {. } \\
\text { The findings of } \\
\text { the study highlight } \\
\text { the need for } \\
\text { identifying cases in } \\
\text { the initial stages of } \\
\text { hospital treatment } \\
\text { for COVID-19 } \\
\text { and begin the } \\
\text { antiviral treatment } \\
\text { before the disease } \\
\text { progresses and } \\
\text { requires mechanical } \\
\text { ventilation. }\end{array}$ \\
\hline $\begin{array}{l}\text { Goldman } \\
\text { et al. }{ }^{12} \text {, } \\
2020\end{array}$ & $\begin{array}{l}\text { To assess the } \\
\text { effectiveness } \\
\text { and safety } \\
\text { of remdesivir } \\
\text { treatment for } 5 \\
\text { or } 10 \text { days } \\
\text { in patients } \\
\text { with severe } \\
\text { COVID-19 } \\
\text { disease }\end{array}$ & RCT & $\begin{array}{l}\text { The individuals in } \\
\text { the study sample } \\
\text { came from different } \\
\text { countries and had } \\
\text { access to treatment in } \\
\text { the clinic. Individuals } \\
\text { already using MV } \\
\text { for randomization } \\
\text { and concomitant } \\
\text { drug treatment were } \\
\text { excluded. } \\
\text { TG5: n=200 } \\
\text { Intravenous remdesivir } \\
\text { for five days: } 200 \text { mg }\end{array}$ & $\begin{array}{c}\text { Mean age: } \\
\text { TG5=61 years } \\
\text { TG10=62 years } \\
\text { Mean days of symptoms } \\
\text { before randomization: } \\
\text { TG5=8/TG10=9 } \\
\text { Associated Comorbidities } \\
\text { (\%): } \\
\text { TG5=SAH (50), Dyslipidemia } \\
\text { (20), DM2 (24) } \\
\text { TG10= SAH (50), Dyslipidemia } \\
\text { (25), DM2 (22) }\end{array}$ & $\begin{array}{l}\text { In this study, } \\
\text { no significant } \\
\text { difference in } \\
\text { effectiveness was } \\
\text { found between } \\
\text { using remdesivir for } \\
5 \text { or } 10 \text { days. }\end{array}$ \\
\hline
\end{tabular}


Table 4. Continuation.

\begin{tabular}{|c|c|c|c|c|c|}
\hline $\begin{array}{l}\text { Author/ } \\
\text { Year }\end{array}$ & $\begin{array}{c}\text { Objective of } \\
\text { the Study }\end{array}$ & $\begin{array}{l}\text { Study } \\
\text { Design } \\
\text { Sample }\end{array}$ & $\begin{array}{l}\text { Description/ } \\
\text { Intervention } \\
\text { Protocol }\end{array}$ & $\begin{array}{l}\text { Results/ } \\
\text { Outcomes }\end{array}$ & Conclusion \\
\hline & & & $\begin{array}{l}\text { on day } 1 \text { and } 100 \mathrm{mg} \\
\text { from day } 2 \text { to day } 4 . \\
\text { TG10: } \mathrm{n}=117 \\
\text { Intravenous remdesivir } \\
\text { for ten days: } 200 \mathrm{mg} \\
\text { on day } 1 \text { and } 100 \mathrm{mg} \\
\text { from day } 2 \text { to day } 9 .\end{array}$ & $\begin{array}{c}\text { Therapeutic Management } \\
\text { Score }(\%) \\
\text { *Not hospitalized } \\
\text { TG5=60/TG } 10=52 \\
\text { *Hospitalization without the } \\
\text { need for supplemental } \mathrm{O}_{2} \\
\text { TG } 5=6 / \mathrm{TG} 10=7 \\
\text { *Hospitalization with } \mathrm{O}_{2} \\
\text { TG5=10/TG } 10=7 \\
\text { *Hospitalization+Non- } \\
\text { invasive ventilation } \\
\text { TG5=4/TG } 10=5 \\
\text { *Hospitalization+invasive } \\
\text { ventilation } \\
\text { TG5=8/TG } 10=17 \\
\text { *Death } \\
\text { TG5=16/TG } 10=21 \\
\text { Recovery Time } \\
\text { Day } 5 \\
\text { TG5=16/TG } 10=14 \\
\text { Day } 7 \\
\text { TG5=36/TG } 10=26 \\
\text { Day } 11 \\
\text { TG5=58/TG } 10=49 \\
\text { Day } 14 \\
\text { TG5=64/TG } 10=54\end{array}$ & \\
\hline $\begin{array}{l}\text { Wang } \\
\text { et al. }{ }^{13}, \\
2020\end{array}$ & $\begin{array}{l}\text { To report the } \\
\text { results found } \\
\text { after using } \\
\text { remdesivir in } \\
\text { adult patients } \\
\text { with severe } \\
\text { symptoms of } \\
\text { COVID-19 } \\
\text { infection }\end{array}$ & $\begin{array}{c}\text { RCT } \\
\text { Multicenter }\end{array}$ & $\begin{array}{l}\text { The individuals in the } \\
\text { study sample came } \\
\text { from hospital health } \\
\text { services in Wuhan, } \\
\text { China. They were } \\
\text { admitted in a serious } \\
\text { condition due to } \\
\text { COVID-19 infection } \\
\text { and were } 12 \text { days or } \\
\text { less from the onset of } \\
\text { symptoms. } \\
\text { TG: } n=155 \\
\text { Intravenous } \\
\text { remdesivir: } 200 \text { mg } \\
\text { on day } 1 \text { and } 100 \text { mg } \\
\text { from day } 2 \text { to day } 10 . \\
\text { PG: } n=78 \\
\text { Received a placebo } \\
\text { infusion on the same } \\
\text { days as the treatment } \\
\text { group. }\end{array}$ & $\begin{array}{c}\text { Mean age } \\
\text { TG=66 years/PG=64 years } \\
\text { Associated Comorbidities } \\
\text { (\%): } \\
\text { TG=SAH (46), CAD (9), DM2 } \\
\text { (25) } \\
\text { PG=SAH (38), CAD (3), DM2 } \\
\text { (21) } \\
\text { Therapeutic } \\
\text { Management Score } \\
\text { *Duration of } \\
\text { invasive } M V \text { (days) } \\
\text { TG=7 days/PG=15.5 days } \\
\text { * Duration of } \\
\text { O support (days) } \\
\text { TG=19 days/PG=21 days } \\
\text { *Hospitalization days } \\
\text { TG=25/PG=24 } \\
\text { *Hospitalization+invasive } \\
\text { ventilation (\%) } \\
\text { TG=23.1/PG=28.2 }\end{array}$ & $\begin{array}{l}\text { Using intravenous } \\
\text { remdesivir did } \\
\text { not significantly } \\
\text { improve the time of } \\
\text { clinical recovery, } \\
\text { mortality, or time to } \\
\text { eliminate the virus } \\
\text { in patients with } \\
\text { severe } \\
\text { CoviD-19 when } \\
\text { compared with the } \\
\text { placebo. } \\
\\
\text { The study is limited } \\
\text { because the } \\
\text { lack of hospital } \\
\text { beds during the } \\
\text { pandemic hindered } \\
\text { patients in earlier } \\
\text { stages of the } \\
\text { symptoms from } \\
\text { being admitted. }\end{array}$ \\
\hline
\end{tabular}


Table 4. Continuation.

\begin{tabular}{|c|c|c|c|c|c|}
\hline \multirow[t]{2}{*}{$\begin{array}{l}\text { Author/ } \\
\text { Year }\end{array}$} & $\begin{array}{l}\text { Objective of } \\
\text { the Study }\end{array}$ & $\begin{array}{l}\text { Study } \\
\text { Design } \\
\text { Sample }\end{array}$ & $\begin{array}{l}\text { Description/ } \\
\text { Intervention } \\
\text { Protocol }\end{array}$ & $\begin{array}{c}\text { Results/ } \\
\text { Outcomes }\end{array}$ & Conclusion \\
\hline & & & & $\begin{array}{c}\text { *Death }(\%) \\
\text { Day } 7 \\
\text { TG=6/PG=5 } \\
\text { Day } 14 \\
\text { TG=10/PG=9 } \\
\text { Day } 28 \\
\text { TG=15/PG=13 } \\
\text { Recovery Time } \\
\text { TG=21 days/PG=23 days } \\
\text { Clinical Improvement Rates } \\
\text { (\%) } \\
\text { Day } 7 \\
\text { TG=3/PG=3 } \\
\text { Day } 14 \\
\text { TG=27/PG=23 } \\
\text { Day } 28 \\
\text { TG=65/PG=58 }\end{array}$ & \\
\hline $\begin{array}{l}\text { Huang } \\
\text { et al. }{ }^{14}, \\
2020\end{array}$ & $\begin{array}{c}\text { To present the } \\
\text { epidemiological, } \\
\text { clinical, } \\
\text { laboratory, } \\
\text { radiological, } \\
\text { treatment, and } \\
\text { clinical results } \\
\text { of patients } \\
\text { with COVID-19 }\end{array}$ & $\begin{array}{l}\text { Cross- } \\
\text { sectional }\end{array}$ & $\begin{array}{l}\text { } \\
\text { } \\
41 \text { hospitalized } \\
\text { patients were } \\
\text { admitted to the } \\
\text { study because they } \\
\text { were diagnosed with } \\
\text { CoviD-19. } \\
\text { The members were } \\
\text { managed with } \\
\text { doses of antibiotics } \\
\text { (orally and } \\
\text { intravenously) and } \\
\text { oseltamivir (75 mg } \\
\text { orally, twice a day). }\end{array}$ & $\begin{array}{c}\text { Age (\%) } \\
20 \text { (49) of infected patients } \\
\text { were between } 25 \\
\text { and } 49 \text { years old, and } 14 \text { (34) } \\
\text { were between } 50 \text { and } 64 \\
\text { years old. } \\
\text { Mean age } \\
\text { The mean age of patients } \\
\text { was } 49 \text { years } \\
\text { Symptoms at the beginning } \\
\text { of the disease } \\
\text { Fever (40), cough (3), and } \\
\text { myalgia or fatigue (1). } \\
\text { Medicines } \\
\text { All patients were } \\
\text { administered empirical } \\
\text { antibiotic treatment and } \\
\text { 38 (93\%) patients received } \\
\text { antiviral therapy (oseltamivir). } \\
\text { Hospital discharge (\%) } \\
\text { On January } 22,2020,28 \\
\text { subsided fever for at least } 10 \\
\text { chest improvement, and viral } \\
\text { (68) of the } 41 \text { patients were } \\
\text { discharged and six (15) died. } \\
\text { the discharge was based on } \\
\text { samples. }\end{array}$ & \\
\hline
\end{tabular}

RCT: randomized clinical trial; USA: United States of America; n: sample number; TG: treatment group; PG: placebo group; SAH: systemic arterial hypertension; DM2: Diabetes Mellitus type 2; COVID-19: coronavirus disease 2019; O2: oxygen; MV: mechanical ventilation; CAD: coronary artery disease. 
to 10 in single daily infusions) or the same volume of placebo infusions for a total of 10 days.

The second study included ${ }^{12}$ involved hospitalized patients aged at least 12 years old and had confirmed COVID-19 infections. For this study, patients were allocated to 55 hospitals from March 6 to $26^{\text {th }}, 2020$. Patients were randomly assigned and received intravenous treatment with remdesivir for 5 or 10 days. All patients received $200 \mathrm{mg}$ remdesivir on the first day, followed by $100 \mathrm{mg}$ remdesivir once daily on subsequent days.

In another study ${ }^{11}, 1,063$ patients were randomly divided into two groups: (1) remdesivir or (2) placebo). Remdesivir was administered intravenously as a dose of $200 \mathrm{mg}$ on day $1 \mathrm{fol}-$ lowed by a maintenance dose of $100 \mathrm{mg}$ administered daily on subsequent days until hospital discharge or until the patient's death. A corresponding placebo was administered in the same way as that of the active drug. In this study, the $236 \mathrm{~b}$ patients were divided into a remdesivir $(\mathrm{n}=158)$ or placebo $(\mathrm{n}=78)$ group. Patients had a mean age of 65 years and the majority were male, 89 (56 \%) in the remdesivir group and 51 (65\%) in the placebo group. The authors observed that patients who received remdesivir had a shorter clinical improvement time compared to those who received placebo (18 versus 23 days $)^{11}$.

For patients assigned to the remdesivir group, the duration of invasive mechanical ventilation (IMV) was shorter compared to the placebo group, suggesting that the use of the drug was more efficient in the remdesivir group. Adverse events were reported in $102(66 \%)$ of 155 patients in the remdesivir group and in 50 (64\%) of 78 subjects in the control group. The most common adverse events in the remdesivir group were hypoalbuminemia, hypokalemia, anemia, and thrombocytopenia; and in the placebo group, constipation and an increase in blood lipids were noted ${ }^{13}$.

In the second study ${ }^{12}, 200$ patients were assigned to receive remdesivir for 5 days and 197 individuals for 10 days. As a result, patients in the 10-day group showed significantly less effective clinical behavior compared to the 5 -day group. In total, $65 \%$ of patients who received remdesivir treatment for 5 days showed significant clinical improvement compared to $54 \%$ of patients who received treatment for 10 days. The median length of hospitalization among discharged patients was seven days for the 5-day group and eight days for the 10-day group (60 and 52\%, respectively), and mortality was numerically lower in the 5-day group compared to the 10 -day group (8 versus $11 \%$ ). The mean recovery time was 10 days among patients in the 5 -day group and 11 days among patients in the 10-day group ${ }^{12}$.

In the third study ${ }^{11}$, of the 1,063 patients who were evaluated, 541 were assigned to the remdesivir group and 522 to the placebo group. The authors reported that patients in the remdesivir group had a shorter recovery time than patients in the placebo group. Serious adverse events occurred in 114 patients (21.1\%) in the remdesivir group and 141 patients $(27.0 \%)$ in the placebo group. Twenty-eight serious adverse events involving respiratory failure in the remdesivir group ( $5.2 \%$ of patients) and 42 in the placebo group ( $8.0 \%$ of patients) occurred. Acute respiratory failure, hypotension, viral pneumonia, and acute kidney injury were somewhat more common among patients in the placebo group. Grade 3 or 4 adverse events occurred in 156 patients $(28.8 \%)$ in the remdesivir group and in the placebo group, 172 (33.0\%) experienced adverse events (Grade 3 or 4).

The most common adverse events in the remdesivir group were anemia or decreased hemoglobin (43 events [7.9\%] compared with 47 [9.0\%] in the placebo group), acute kidney injury, decreased estimated glomerular filtration rate, creatinine clearance and/or increased blood creatinine (40 events [7.4\%] compared with 38 [7.3\%]), pyrexia (27 events [5.0\%] compared to 17 [3.3\%]), hyperglycemia or increased blood glucose level (22 events [4.1\%] compared with 17 [3.3\%]), and increased levels of aminotransferases, including alanine aminotransferase, aspartate aminotransferase, or both (22 events [4.1\%], compared with $31[5.9 \%])^{11}$.

In the study by Huang et al. ${ }^{14}$, doses of antibiotics (orally and intravenously) and oseltamivir (orally, $75 \mathrm{mg}$ twice daily) were administered to 41 participating patients. Of these, 20 (49\%) infected patients were between 25 and 49 years old, and $14(34 \%)$ were between 50 and 64 years old. The mean age of patients was 49 years, and $13(32 \%)$ were admitted to the ICU, provided they needed a high-flow nasal cannula or higher-level oxygen support measures to correct hypoxemia. The most common symptoms upon disease presentation were fever $(n=40[98 \%])$, cough $(n=31[76 \%])$, and myalgia or fatigue $(n=18[44 \%])$. More than half of the patients $(\mathrm{n}=22[55 \%])$ developed dyspnea. All patients were administered empirical antibiotic treatment and $\mathrm{n}=38(93 \%)$ patients received antiviral therapy (oseltamivir). On January $22^{\text {nd }}, 2020$, $28(68 \%)$ of the 41 patients were discharged and six (15\%) died. The condition for discharge was based on the reduction of fever for at least 10 days with concurrent improvement in radiographic evidence of the chest and viral release in upper respiratory tract samples ${ }^{14}$.

\section{DISCUSSION}

This research aimed to verify the importance of therapeutic intervention in the initial stages after a COVID-19 infection in order to prevent the evolution of symptoms. It was found in the studies in which drugs used in the COVID-19 population were analyzed that the drugs were effective for the time of clinical improvement ${ }^{13}$, led to shorter times to discharge 
from the hospital, and caused a decrease in the use of invasive mechanical ventilation (IMV) ${ }^{11-13}$. However, research has also reported adverse reaction to medications ${ }^{12,13}$ and more than 5 days of drug administration led to less effective drug efficiency $^{12}$. It is important to highlight that the placebo groups also had health-related adverse effects. From this analysis, the importance of developing research with a larger population that seeks to verify scientific evidence is highlighted, as well as elucidating the effectiveness of drugs with early intervention in patients diagnosed with COVID-19. To date, no therapy has proven effective to the point of being advised for patients with COVID-19, but it is noteworthy that several ongoing randomized controlled trials will provide more meaningful information regarding the effectiveness of drugs used to treat it.

A study carried out by Grein et al. ${ }^{15}$ demonstrated that hospitalized COVID-19 patients who were in serious condition and treated with compassionate remdesivir presented clinical improvement in 36 of the 53 patients (68\%). These data corroborate the findings of the present research ${ }^{11-13}$. However, in one of the studies ${ }^{13}$, the authors reported that remdesivir did not result in significant reductions in SARS-CoV-2 RNA loads in patients with severe disease stage or in detectability in upper respiratory tract samples, despite having observed strong antiviral effects in preclinical models of coronavirus infection. However, the pharmacokinetics of remdesivir in the respiratory tract cells of critically ill patients is unknown ${ }^{16}$.

Regarding mortality, lower rates were observed in patients in the 5-day group who received the remdesivir dose compared to the 10 -day group ( 8 versus $11 \%)^{12}$. In a recent, controlled, and randomized study in which drugs for patients hospitalized by COVID- 19 were used, the mortality at 28 days was $22 \%{ }^{17}$.

In addition, remdesivir-related adverse events, such as hypoalbuminemia, hypokalemia, anemia, and thrombocytopenia, were reported in two studies ${ }^{11,13}$. However, in a previous study ${ }^{18}$, patients significantly improved, and no adverse effects were observed. The current dose recommendation for remdesivir in COVID-19 is $200 \mathrm{mg}$ (loading dose) on the first day followed by $100 \mathrm{mg}$ on subsequent days ${ }^{19}$. In the studies presented in this analysis ${ }^{11-14}$, both used the dosage according to this indication.

With regard to other administered drugs, one study ${ }^{14}$ used antibiotics and oseltamivir in its patient sample. Although COVID-19 is a viral disease, initial hospital data shows that patients are being treated with antibiotics to cure or protect against secondary infections during respiratory illness or hospitalization. Two studies ${ }^{20,21}$ reported improvement in the clinical picture with the use of antibiotic therapy and another associated medications without the evolution of the picture for bacterial infection. However, as reported by two other studies ${ }^{22,23}$, patients' clinical conditions were not improved with the early initiation of antibiotic therapy.

Oseltamivir has no documented in vitro activity against SARS-CoV-2. However, its use is indicated in patients with severe acute respiratory syndrome or flu-like syndrome ${ }^{24}$. To assess the outcome of in vitro evidence suggesting that zinc may be effective against COVID-19, a study compared patients who received hydroxychloroquine and azithromycin in combination with zinc in patients who received hydroxychloroquine or azithromycin. As a result, the authors emphasize that the addition of zinc did not affect the length of hospital stay, ventilation duration, or the length of stay in the ICU ${ }^{25}$. Another study, with the aim of evaluating the role of hydroxychloroquine for the treatment of patients diagnosed with COVID-19, compared 821 participants who started treatment with hydroxychloroquine or placebo. No significant differences in the incidence of new cases between the two groups were noted, and side effects were greater in the hydroxychloroquine group $(40.1 \%)$ compared to the other group (16.8\%). No serious adverse effects were reported ${ }^{26}$.

However, a study by Gautret et al. ${ }^{27}$, which involved treatment with hydroxychloroquine combined with azithromycin, showed a negative viral titer in all patients who used this treatment combination. So far, the effectiveness and safety of this intervention for patients with SARS-CoV-2 infection are considered inconclusive. Caution is recommended with respect to the use of this association.

In Brazil, some medical teams use a combination of hydroxychloroquine and azithromycin in the population, and are currently achieving positive levels of effectiveness with this intervention, significantly reducing hospitalizations and virus-associated effects, thus demonstrating treatment effectiveness ${ }^{28-30}$.

\section{CONCLUSION}

Patients submitted to treatment with certain antiviral drugs were less likely to have complications during the hospital stay, in addition to having less symptom evolution and a sooner hospital discharge. However, adverse events may occur in individuals submitted to such medication. Considering the studies included in this research, the importance of therapeutic interventions in the initial phases of the infection is evident, aiming to minimize viral activity with a reduced length of hospital stay and a direct impact on health costs, as the number of patients in ICU beds decreased significantly.

It should be noted that there is a considerable range of antiviral drugs being studied, and the specific indication of any given medicine must be adjusted - regarding its dosages 
as well. The combination of some of these medications has proven effective and must be studied in a broader population while highlighting that the existing studies have already demonstrated important therapeutic possibilities to treat COVID-19.

\section{AUTHORS" CONTRIBUTION}

LFG: Methodology, Formal Analysis. GSC: Investigation. KMP: Data Curation, Resources. AIG: Validation, Visualization.

PH: Conceptualization, Supervision.

\section{REFERENCES}

1. Zhang $X$, Tan Y, Ling Y, Lu G, Liu F, Yi Z, et al. Viral and host factors related to the clinical outcome of COVID-19. Nature. 2020;583(7816):437-40. https://doi.org/10.1038/s41586020-2355-0

2. Speth MM, Singer-Cornelius T, Oberle M, Gengler I, Brockmeier SJ, Sedaghat AR. Olfactory dysfunction and sinonasal symptomatology in COVID-19: prevalence, severity, timing, and associated characteristics. Otolaryngol Head Neck Surg. 2020;163(1):114-20. https://doi. org/10.1177/0194599820929185

3. World Health Organization. Folha informativa - COVID-19 (doença causada pelo novo coronavírus). Geneva: World Health Organization; 2020. [cited on Jul. 11, 2020]. Available from: https://www.paho.org/bra/index.php?option=com_content \&amp;view=article\&amp;id=6101: covid19\&amp;/temid=87 5\#datas-noticificacoes

4. Chakraborty C, Sharma AR, Sharma G, Bhattacharya M, Lee SS. SARS-CoV-2 causing pneumonia-associated respiratory disorder (COVID-19): diagnostic and proposed therapeutic options. Eur Rev Med Pharmacol Sci. 2020;24(7):4016-26. https://doi.org/10.26355/eurrev_202004_20871

5. Valentini M, Zmerly H. Antirheumatic drugs for COVID-19 treatment based on the phases of the disease: current concept. J Popul Ther Clin Pharmacol. 2020;27(S Pt 1):e14-25. https:// doi.org/10.15586/jptcp.v27iSP1.689

6. Horisberger A, Moi L, Ribi C, Comte D. Impact of COVID-19 pandemic on SLE: beyond the risk of infection. Lupus Sci Med. 2020;7(1):e000408. https://doi.org/10.1136/lupus2020-000408

7. Ding $Y$, Wang $H$, Shen $H$, Li Z, Geng J, Han $H$. The clinical pathology of severe acute respiratory syndrome (SARS): a report from China. J Pathol. 2003;200(3):282-9. https://doi. org/10.1002/path.1440

8. Michael D. COVID-19: identifying and isolating asymptomatic people helped eliminate virus in Italian village. BMJ. 2020;368:m1165. https://doi.org/10.1136/bmj.m1165

9. Siddiqi HK, Mehra MR. COVID-19 illness initiative and immunosuppressed states: a clinical-therapeutic staging proposal. J Heart Lung Transplant. 2020;39(5):405-7. https:// doi.org/10.1016/j.healun.2020.03.012

10. Moher D, Shamseer L, Clarke M, Ghersi D, Liberati A, Petticrew $M$, et al. Preferred reporting items for systematic review and meta-analysis protocols (PRISMA-P) 2015 statement. Syst Rev. 2015;4(1):1. https://doi.org/10.1186/2046-4053-4-1

11. Beigel JH, Tomashek KM, Dodd LE, Mehta AK, Zingman BS, Kalil AC, et al. Remdesivir for the treatment of COVID-19: final report. N Engl J Med. 2020;383(19):1813-26. https:// doi.org/10.1056/NEJMoa2007764

12. Goldman JD, Lye DCB, Hui DS, Marks KM, Bruno R, Montejano $\mathrm{R}$, et al. Remdesivir for 5 or 10 days in patients with severe
COVID-19. N Engl J Med. 2020;383(19):1827-37. https://doi. org/10.1056/NEJMoa2015301

13. Wang Y, Zhang D, Du G, Du R, Zhao J, Jin Y, et al. Remdesivir in adults with severe COVID-19: a randomised, double-blind, placebocontrolled, multicentre trial. Lancet. 2020;395(10236):1569-78. https://doi.org/10.1016/S0140-6736(20)31022-9

14. Huang $C$, Wang $Y$, Li $X$, Ren $L$, Zhao J, Hu Y, et al. Clinical features of patients infected with 2019 novel coronavirus in Wuhan, China. Lancet. 2020;395(10223):497-506. https:// doi.org/10.1016/S0140-6736(20)30183-5

15. Grein J, Ohmagari N, Shin D, Diaz G, Asperges E, Castagna $A$, et al. Compassionate use of remdesivir for patients with severe COVID-19. N Engl J Med. 2020;382(24):2327-36. https://doi.org/10.1056/NEJMoa2007016

16. Jacobs M, Rodger A, Bell DJ, Bhagani S, Cropley I, Filipe A, et al. Late Ebola virus relapse causing meningoencephalitis: a case report. Lancet. 2016;388(10043):498-503. https://doi. org/10.1016/S0140-6736(16)30386-5

17. Cao B, Wang Y, Wen D, Liu W, Wang J, Fan G, et al. A trial of lopinavir-ritonavir in adults hospitalized with severe COVID-19. N Engl J Med. 2020;382(19):1787-99. https://doi.org/10.1056/ NEJMoa2001282

18. Ko WC, Rolain JM, Lee NY, Chen PL, Huang CT, Lee PI, et al. Arguments in favour of remdesivir for treating SARS-CoV-2 infections. Int J Antimicrob Agents. 2020;55(4):105933. https://doi.org/10.1016/j.ijantimicag.2020.105933

19. Singh AK, Singh A, Singh R, Misra A. Remdesivir in COVID19: a critical review of pharmacology, pre-clinical and clinical studies. Diabetes Metab Syndr. 2020;14(4):641-648. https:// doi.org/10.1016/j.dsx.2020.05.018

20. Browne PC, Linfert JB, Perez-Jorge E. Successful treatment of preterm labor in association with acute COVID-19 infection. Am J Perinatol. 2020;37(8):866-8. https://doi. org/10.1055/s-0040-1709993

21. Kamali Aghdam M, Jafari N, Eftekhari K. Novel coronavirus in a 15-day-old neonate with clinical signs of sepsis: a case report. Infect Dis (Lond). 2020;52(6):427-9. https://doi.org/ 10.1080/23744235.2020.1747634

22. Huang J, Lin H, Wu Y, Fang Y, Kumar R, Chen G, et al. COVID-19 in posttransplant patients-report of 2 cases. Am J Transplant. 2020;20(7):1879-81. https://doi.org/10.1111/ajt.15896

23. Righi G, Del Popolo G. COVID-19 tsunami: the first case of a spinal cord injury patient in Italy. Spinal Cord Ser Cases. 2020;6(1):22. https://doi.org/10.1038/s41394-020-0274-9

24. Uyeki TM, Bernstein HH, Bradley JS, Englund JA, File TM, Fry AM, et al. Clinical practice guidelines by the Infectious Diseases Society of America: 2018 update on diagnosis, treatment, chemoprophylaxis, and institutional outbreak management of seasonal influenza. Clin Infect Dis. 2019;68(6):895-902. https://doi.org/10.1093/cid/ciy874 
25. Carlucci P, Ahuja T, Petrilli CM, Rajagopalan H, Jones S, Rahimian J. Hydroxychloroquine and azithromycin plus zinc vs hydroxychloroquine and azithromycin alone: outcomes in hospitalized COVID-19 patients. MedRxiv. 2020:20080036. https://doi.org/10.1101/2020.05.02.20080036

26. Boulware DR, Pullen MF, Bangdiwala AS, Pastick KA, Lofgren $\mathrm{SM}$, Okafor EC, et al. A randomized trial of hydroxychloroquine as postexposure prophylaxis for COVID-19. N Engl J Med. 2020;383(6):517-25. https://doi.org/10.1056/NEJMoa2016638

27. Gautret P, Lagier JC, Parola P, Hoang VT, Meddeb L, Mailhe $M$. Hydroxychloroquine and azithromycin as a treatment of COVID-19: results of an open-label non-randomized clinical trial. Int J Antimicrob Agents. 2020;56(1):105949. https:// doi.org/10.1016/j.ijantimicag.2020.105949

28. BRASIL. Prefeitura de Porto Feliz. COVID-19 [internet]. 2020; [cited on Jul. 13, 2020]. Available from: https://www.portofeliz. sp.gov.br/

29. BRASIL. Secretaria de Estado de Saúde. Tratamento para a COVID-19 [internet]. 2020; [cited on Jul. 13, 2020]. Available from: http://www.saude.am.gov.br/

30. UNIMED Belém. Tratamento para COVID-19 [internet]. 2020; [cited on Jul. 13, 2020]. Available from: https://www. unimedbelem.com.br/ 